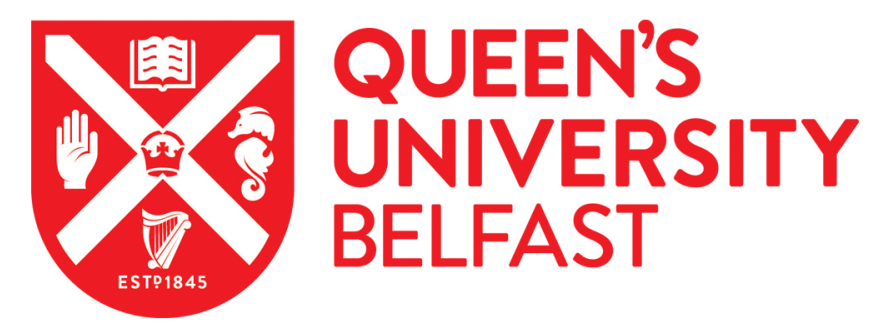

\title{
Novel DGT method with tri-metal oxide adsorbent for in situ spatiotemporal flux measurement of fluoride in waters and sediments
}

Zhou, C. Y., Guan , D-X., Williams, P. N., Luo, J., \& Ma, L. Q. (2016). Novel DGT method with tri-metal oxide adsorbent for in situ spatiotemporal flux measurement of fluoride in waters and sediments. Water Research, 99, 200-208. https://doi.org/10.1016/j.watres.2016.04.062

Published in:

Water Research

Document Version:

Peer reviewed version

Queen's University Belfast - Research Portal:

Link to publication record in Queen's University Belfast Research Portal

Publisher rights

(C) 2016, Elsevier Ltd.

This is an open access article published under a Creative Commons Attribution-NonCommercial-NoDerivs License

(https://creativecommons.org/licenses/by-nc-nd/4.0/), which permits distribution and reproduction for non-commercial purposes, provided the author and source are cited.

\section{General rights}

Copyright for the publications made accessible via the Queen's University Belfast Research Portal is retained by the author(s) and / or other copyright owners and it is a condition of accessing these publications that users recognise and abide by the legal requirements associated with these rights.

Take down policy

The Research Portal is Queen's institutional repository that provides access to Queen's research output. Every effort has been made to ensure that content in the Research Portal does not infringe any person's rights, or applicable UK laws. If you discover content in the Research Portal that you believe breaches copyright or violates any law, please contact openaccess@qub.ac.uk. 

Lab characterization
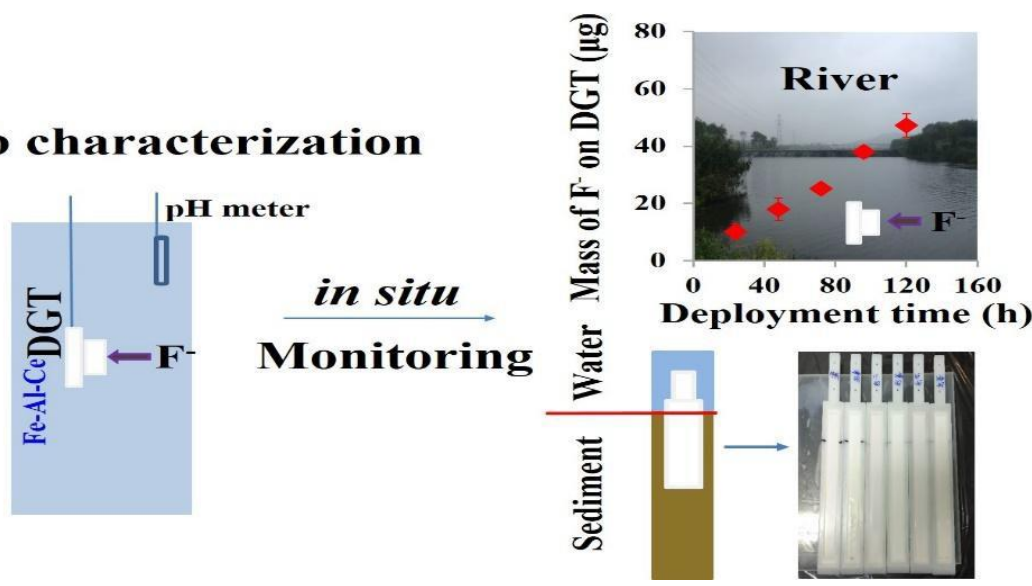

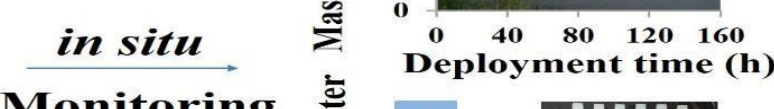

Monitoring

言 
1 Novel DGT method with tri-metal oxide adsorbent for in situ

2 spatiotemporal flux measurement of fluoride in waters and sediments

3

4 Chun-Yang Zhou ${ }^{1}$, Dong-Xing Guan ${ }^{1}$, Paul N. Williams ${ }^{2}$, Jun Luo ${ }^{1, *}$, Lena Q. Ma ${ }^{1,3}$

5

$6{ }^{1}$ State Key Laboratory of Pollution Control and Resource Reuse, School of the

7 Environment, Nanjing University, Nanjing 210023, People's Republic of China

82 Institute for Global Food Security, School of Biological Sciences, Queen's

9 University Belfast, Belfast BT9 7BL, United Kingdom

$10{ }^{3}$ Soil and Water Science Department, University of Florida, Gainesville, FL 32611, 11 USA

12

13

14

15

$16 *$ Corresponding authors, 0086-25-89680632, esluojun@ nju.edu.cn 


\section{ABSTRACT}

Natural mineral-water interface reactions drive ecosystem/global fluoride $\left(\mathrm{F}^{-}\right)$cycling.

These small-scale processes prove challenging to monitoring due to mobilization being highly localized and variable; influenced by changing climate, hydrology, dissolution chemistries and pedogenosis. These release events could be captured in situ by the passive sampling technique, diffusive gradients in thin-films (DGT), providing a cost-effective and time-integrated measurement of $\mathrm{F}^{-}$mobilization. However, attempts to develop the method for $\mathrm{F}^{-}$have been unsuccessful due to the very restrictive operational ranges that most $\mathrm{F}^{-}$-absorbents function within. A new hybrid-DGT technique for $\mathrm{F}^{-}$quantification containing a three-phase fine particle composite (Fe-Al-Ce, FAC) adsorbent was developed and evaluated. Sampler response was validated in laboratory and field deployments, passing solution chemistry QC within ionic strength and $\mathrm{pH}$ ranges of 0-200 $\mathrm{mmol} \mathrm{L}^{-1}$ and 4.3-9.1, respectively, and exhibiting high sorption capacities $\left(98 \pm 8 \mu \mathrm{g} \mathrm{cm}^{-2}\right)$. FAC-DGT measurements adequately predicted up to weeklong averaged in situ $\mathrm{F}^{-}$fluvial fluxes in a freshwater river and $\mathrm{F}^{-}$concentrations in wastewater treatment flume pond determined by high frequency active sampling. While, millimetre-scale diffusive fluxes across the sediment-water interface were modeled for three contrasting lake bed sediments from a $\mathrm{F}^{-}$-enriched lake using the new FAC-DGT platform.

Keywords: fluoride; diffusive gradients in thin-films; sediment; surface water 


\section{Introduction}

Fluoride $\left(\mathrm{F}^{-}\right)$is required for the formation and upkeep of bones and dental enamel (Jha et al., 2011). In the US alone, it has been estimated that $\sim 85 \%$ of adults have experienced enhanced tooth decay owing to $\mathrm{F}^{-}$deficiency (Perumal et al., 2013; Su et al., 2013). However, the therapeutic range is very narrow and in excess can disrupt thyroid metabolism, impair brain function, cause bone deformities, and in severe cases result in paralysis and cancer (Harrison, 2005; Meenakshi and Maheshwari, 2006; Viswanathan et al., 2009). Drinking water is the predominant source of $\mathrm{F}^{-}$ intake by humans (Amini et al., 2008), yet still, more than 200 million people worldwide rely on water sources with $\mathrm{F}^{-}$concentrations above the World Health Organization's maximum contaminant level of $1.5 \mathrm{mg} \mathrm{L}^{-1}$ (Fawell et al., 2006; Jha et al., 2011).

Optimizing $\mathrm{F}^{-}$intakes from potable water supplies is a grand challenge. Not only is it a common mineral constituent, subject to frequent and irregular enrichment in rocks, but when dissolved has no discernable taste, odor or colour (Viswanathan et al., 2009). At neutral or high $\mathrm{pH}$, dissolved fluorides are predominantly present as $\mathrm{F}^{-}$, with $\mathrm{HF}$ forming at low $\mathrm{pH}$ (Ghosh et al., 2013). Yet, it is the fluctuation in $\mathrm{F}^{-}$ concentrations, both spatially and temporally, which depends not only on water chemistries, with key parameters being high $\mathrm{pH}$ and the concentrations of other ions such as $\mathrm{Cl}^{-}, \mathrm{SO}_{4}{ }^{2-}, \mathrm{Na}^{+}, \mathrm{Ca}^{2+}, \mathrm{Al}^{3+}$ and $\mathrm{HCO}_{3}{ }^{-}$(Hu et al., 2013), but also hydrological properties including residence time, and climatic conditions like evapotranspiration and precipitation that make $\mathrm{F}^{-}$concentrations difficult to predict (Amini et al., 2008). 
Numerous methodologies have been applied to the measurement of $\mathrm{F}^{-}$in waters and sediments, including $\mathrm{F}^{-}$selective electrodes (Perdikaki et al., 2002), ion chromatography (Hoop et al., 1996; Severi et al., 2014), fluorescence capillary electrophoresis (Hoop et al., 1996), ${ }^{19}$ F nuclear magnetic resonance spectra (Zeng and Stebbins, 2000) and colorimetric determination (Zhu et al., 2005). Although some of these methods are sensitive, they have rarely been used in field analysis owing to their non-portability (Sun et al., 2014). Meanwhile, usually combined with field/active sampling, these methods only capture at best an instantaneous solid-water pseudo-equilibrium or at worst alter this balance during sample collection, which can result in a false impression of localized conditions over time. $\mathrm{F}^{-}$selective electrodes are the main method for in situ $\mathrm{F}^{-}$measurement, however the technique's narrow application range, a restriction imposed by the sensitivity to varying $\mathrm{pH}$ and interference ions like $\mathrm{Al}^{3+}$ (Perdikaki et al., 2002), and above all a low accuracy, drives the need for alternative, more field practical techniques. Furthermore, taking high-resolution 2D measurements at soil/sediment-water interfaces with electrodes without compromising the integrities of the monitored chemistries is a challenge.

Passive samplers (PS) are a promising approach for overcoming the above-mentioned limitations, providing a means to obtain multi-dimensional (temporal/spatial) data in a cost effective manner with minimal disturbance to the sampling environment (Vrana et al., 2005). The diffusive gradient in thin-films (DGT) technique is one of the most widely adopted PS techniques and has been comprehensively validated for the measurement of labile metals, phosphate and 
mercury (Gao et al., 2011; Guan et al., 2015; Luo et al., 2010; Santner et al., 2010; Zhang and Davison, 1995). With DGT samplers, the target of interest diffuses through an inert filter membrane hydrogel stack, driven by a concentration differential generated by immobilization of the analyte to a binding layer (Davision and Zhang, 1994). Chelex and ferrihydrite have been widely used as the binding agent to measure cations and oxyanions, respectively (Luo et al., 2010; Zhang and Davison, 1995). However, a suitable binding layer to enable $\mathrm{F}^{-}$measurement by DGT, one that can function across a wide range of pH's with sufficient tolerance to competitive ions to make the measurements environmentally relevant, has yet to be developed.

Rare earth elements exhibit a general trend for both selectivity and a high adsorption capacity for $\mathrm{F}^{-}$(Zhou et al., 2004). Among them, hydrous $\mathrm{Ce}(\mathrm{IV}$ ) oxide has superior performance characteristics for $\mathrm{F}^{-}$adsorption (Tokunaga et al., 1995). To improve the application range of the Ce oxide adsorbent (the optimum adsorption is at pH 2 (Tokunaga et al., 1995) in water), the oxide can be mixed with other metals such as $\mathrm{Al}(\mathrm{III})$ with a higher $\mathrm{pH}_{\mathrm{zpc}}$ (ZPC, zero point charge) of over 8 (Das et al., 2003). To complete the optimization a third species with an overlapping ZPC to that of Ce-oxide such as $\mathrm{Fe}(\mathrm{II})$, can also be included into the mix to reduce the economic costs of the binding phase by lessening the Ce-oxide requirement, whilst maintaining a high $\mathrm{F}^{-}$ adsorption capacity (Wu et al., 2007). Adsorbents made by co-precipitation of Fe(II), $\mathrm{Al}(\mathrm{III})$ and $\mathrm{Ce}(\mathrm{IV})$ salt solutions exhibit a strong ability to adsorb $\mathrm{F}^{-}$in a wide range of waters covering acidic to alkaline conditions (Wu et al., 2007; Zhang et al., 2005). The overall aim of this study is to develop and validate a practical and cost 
effective hybrid-DGT method for $\mathrm{F}^{-}$measurement based on a triple composite adsorbent, optimized for water and sediment conditions/environments. Sub-aims were: develop a casting procedure for the encapsulation of a Fe-Al-Ce (FAC) oxide mixture within a gel matrix; characterize both the diffusion coefficient of $\mathrm{F}$ in the diffusive gel and the elution efficiency of $\mathrm{F}^{-}$from the novel FAC oxides based binding gels; ascertain the performance responses of the DGT containing the FAC gels (FAC-DGT) to different ionic strengths, $\mathrm{pH}$, aging times, deployment times, and diffusive gel thicknesses; determine the sensitivity of method; validate the samplers in natural water and $\mathrm{F}^{-}$-containing wastewater deployment scenarios, and measure the sediment-water interface reactions impacting on $\mathrm{F}^{-}$geochemistry using this novel hybrid-DGT method.

\section{Material and methods}

\subsection{Preparation of solutions, new binding gels and DGT devices}

The chemicals used in this study were of analytical reagent grade or above. $\mathrm{F}^{-}$stocksolution was prepared at $1000 \mathrm{mg} \mathrm{L}^{-1}$ using sodium fluoride. All solutions used in this experiment were prepared using high purity water (18.2 M $\Omega-\mathrm{cm}$, Milli-Q, Millipore, USA).

A standard cylindrical DGT device is comprised of a plastic base, a binding gel layer, a diffusive gel layer, a 0.14-mm-thick, $0.45-\mu \mathrm{m}$ pore size filter membrane (Pall Co. USA), and a plastic cap with a circular exposure window of $2.51 \mathrm{~cm}^{2}$ (Guan et al., 2015; Warnken et al., 2005).

To prepare the new binding gel, a FAC oxide mixture was used as the anion 
sorbent. A solution containing $0.1 \mathrm{~mol} \mathrm{~L}^{-1} \mathrm{Fe}^{2+}, 0.2 \mathrm{~mol} \mathrm{~L}^{-1} \mathrm{Al}^{3+}$, and $0.1 \mathrm{~mol} \mathrm{~L}^{-1} \mathrm{Ce}^{4+}$ was prepared by dissolving $\mathrm{FeSO}_{4} \cdot 7 \mathrm{H}_{2} \mathrm{O}, \mathrm{Al}_{2}\left(\mathrm{SO}_{4}\right)_{3} \cdot 8 \mathrm{H}_{2} \mathrm{O}, \mathrm{Ce}\left(\mathrm{SO}_{4}\right)_{2} \cdot 4 \mathrm{H}_{2} \mathrm{O}$ in MQ water. The $\mathrm{pH}$ of the mixed solution was adjusted using saturated $\mathrm{NaOH}$ solution under vigorous stirring. Precipitation of yellowish-brown FAC oxides mixture formed when $\mathrm{pH}$ reached 8 . The mixture was then washed with MQ water and centrifuged at $3600 \mathrm{~g}$ for $10 \mathrm{~min}$ followed by repeated washing and centrifugation until the $\mathrm{pH}$ of the supernatant was $\sim 6.5$. Then the FAC oxides mixture was collected, dried at $65^{\circ} \mathrm{C}$ for $24 \mathrm{~h}$ and calcined at $300^{\circ} \mathrm{C}$ for $3 \mathrm{~h}$. After that, the dried mixture was ground to fine powder and passed through $150 \mu \mathrm{m}$ sieve (Wu et al., 2007). $1.4 \pm 0.1 \mathrm{~g}$ of the FAC powder was vigorously mixed with $8 \mathrm{~mL}$ gel solution, which contains $37.5 \%$ acrylamide solution (w/w), 47.5\% MQ water and $15 \%$ patented cross-linker (Stockdale et al., 2008), until the powder was fully dispersed in the gel solution. Then the gel solution was mixed well with $52 \mu \mathrm{L}$ of $10 \%$ ammonium persulphate solution followed by $12.8 \mu \mathrm{L} N, N, N^{\prime} N^{\prime}$-Tetramethylethylenediamine (TEMED, 99\%, Electran, $\mathrm{BDH})$.

The gels were cast by pipetting the mixture solution between two acid-washed glass plates separated by 0.25 -mm-thick plastic spacer and set in an oven at $44 \pm 2{ }^{\circ} \mathrm{C}$ for $1 \mathrm{~h}$ to allow the gel to polymerize. Then the completely solidified gels were hydrated with MQ water that was changed 3-4 times during 24 h. Finally, the fully hydrated FAC gels were stored in $0.01 \mathrm{~mol} \mathrm{~L}^{-1} \mathrm{NaNO}_{3}$ solution prior to use (Zhang and Davison, 1995). Detailed information about the preparation of diffusive gel is available in the Supplementary Material (SM). 


\subsection{Analytical method and DGT concentration calculation}

In this study, the binding layers (FAC gels) were eluted using $3 \mathrm{~mL}$ of $0.1 \mathrm{~mol} \mathrm{~L}^{-1}$ $\mathrm{NaOH}$ for approximately $24 \mathrm{~h} . \mathrm{F}^{-}$concentrations in eluates were measured with the SPADNS (sodium 2-(parasulfophenylazo)-1,8-dihydroxy-3,6-naphthalene disulfonate) method using a spectrophotometer (UV-2550, Shimadzu, Japan) (Ghosh et al., 2013). In short, $\mathrm{F}^{-}$-eluates were adjusted to $\mathrm{pH}$ 6-7 with $1 \mathrm{~mol} \mathrm{~L}^{-1} \mathrm{HCl}$. Next, $0.5 \mathrm{~mL}$ of freshly prepared SPADNS solution was well mixed with $3 \mathrm{~mL}$ pre-acidified eluate followed by water-bath heating at $35^{\circ} \mathrm{C}$ for $30 \mathrm{~min}$ before UV-VIS spectrophotometer (SPADNS-Vis-S) measurements at $570 \mathrm{~nm}$ (Pillai et al., 2012). Detailed information on preparation of the SPADNS solution is available in the SM.

The mass, $M$, of $\mathrm{F}^{-}$in the binding gel, was calculated by equation 1 (Eq. 1) (Zhang and Davison, 1995):

$$
M=C_{\mathrm{e}} \times\left(V_{\mathrm{NaOH}}+V_{\mathrm{gel}}+V_{\mathrm{HCl}}\right) / f_{\mathrm{e}}
$$

$C_{\mathrm{e}}$ is the concentration of $\mathrm{F}^{-}$in elution samples, $V_{\mathrm{NaOH}}$ is the volume of added elution reagent, $V_{\text {gel }}$ is the volume of the binding gel, which is $0.16 \mathrm{~mL}, V_{\mathrm{HCl}}$ is the volume of $\mathrm{HCl}$ added into elution samples for adjusting $\mathrm{pH}$, and $f_{\mathrm{e}}$ is the elution efficiency.

The concentration measured by DGT, $\mathrm{C}_{\mathrm{DGT}}$, was calculated by Eq. 2 (Zhang and Davison, 1995):

$$
C_{\text {DGT }}=M \times \Delta g /(D \times A \times t)
$$

$\Delta g(\mathrm{~cm})$ represents the combined thickness of the filter and the diffusive gel, $D\left(\mathrm{~cm}^{2}\right.$ $\left.\mathrm{s}^{-1}\right)$ is the diffusion coefficient of $\mathrm{F}^{-}, t(\mathrm{~s})$ is the deployment time, and $A\left(\mathrm{~cm}^{2}\right)$ is the area of the sampling window of DGT devices. 
173

174

175

176

177

178

179

180

181

182

183

184

185

186

187

188

189

190

191

192

193

194

\subsection{Elution efficiency (fe) of FAC gels}

Accurate calculation of accumulated $\mathrm{F}^{-}$mass on the FAC gels depends on the quantitative recovery of $\mathrm{F}^{-}$from it, which derives an important parameter, $f_{\mathrm{e}}$. In this study, $f_{\mathrm{e}}$ of $\mathrm{F}^{-}$was obtained by eluting FAC gels discs loaded with different masses of $\mathrm{F}(10,50$, and $200 \mu \mathrm{g})$ in $3 \mathrm{~mL}$ of $0.1,0.5$, or $1 \mathrm{~mol} \mathrm{~L}^{-1}$ freshly prepared $\mathrm{NaOH}$ for at least $24 \mathrm{~h}$.

\subsection{Measurement and calculation of diffusion coefficient (D)}

Diffusion coefficient (D) of $\mathrm{F}^{-}$in the diffusive gel were measured using a previously described diffusion cell (Pan et al., 2015; Zhang and Davision, 1999), which comprised of two compartments (one as the source and the other as the receptor) connected by a $1.5-\mathrm{cm}$ diameter circular window containing a 0.8 -mm-thick diffusive gel. Both compartments were filled with $50 \mathrm{~mL}$ of $0.01 \mathrm{~mol} \mathrm{~L}^{-1} \mathrm{NaNO}_{3}$ solution at $\mathrm{pH}$ 6.0. The solution in the source compartment contained $100 \mathrm{mg} \mathrm{L}^{-1} \mathrm{~F}^{-}$, while the receptor compartment solution was devoid of $\mathrm{F}^{-}$. The solutions in each compartment were well stirred during the experiments. Subsamples $(0.5 \mathrm{~mL})$ were simultaneously collected from both compartments at intervals of 30 min over a period of $3.5 \mathrm{~h}$. Measurement biases can be invoked with the large sample volumes required $(3 \mathrm{~mL})$ for the SPADNS spectrophotometric method, so all subsamples from the two compartments were analyzed by using an Ion Chromatograph method (IC-1000, Dionex, USA).

\subsection{Effect of $\mathrm{pH}$, ionic strength and deployment time on DGT uptake}

The effect of $\mathrm{pH}$ on accumulation of $\mathrm{F}^{-}$by DGT was tested by deploying DGT devices 
containing FAC gels and 0.8-mm-thick diffusion gels in $2 \mathrm{~L}$ of $1 \mathrm{mg} \mathrm{L}^{-1} \mathrm{~F}^{-}$and 0.01 mol $\mathrm{L}^{-1} \mathrm{NaNO}_{3}$ solutions at different $\mathrm{pH}$, ranging from 3.2 to 9.1 , for $4 \mathrm{~h}$. To study how ionic strength affected DGT uptake of $\mathrm{F}^{-}$, DGT devices were immersed in $2 \mathrm{~L}$ of solutions at pH 6.0 containing $1 \mathrm{mg} \mathrm{L}^{-1} \mathrm{~F}^{-}$and different concentrations of $\mathrm{NaNO}_{3}(0,1$, 5, 10, 20, 50, 100, $200 \mathrm{mmol} \mathrm{L}^{-1}$ ) for $4 \mathrm{~h}$. To monitor DGT performance with increasing deployment time, DGT assemblies were deployed in 6 L solutions containing $1 \mathrm{mg} \mathrm{L}^{-1} \mathrm{~F}^{-}$and $0.01 \mathrm{~mol} \mathrm{~L}^{-1} \mathrm{NaNO}_{3}$ for deployment times ranging from 4 to $72 \mathrm{~h}$.

\subsection{Capacity and aging effect}

To measure the capacity of FAC gels, the FAC-DGT units were deployed for $4 \mathrm{~h}$ in 2 L of well-stirred $0.01 \mathrm{~mol} \mathrm{~L}^{-1} \mathrm{NaNO}_{3}$ solutions at $\mathrm{pH} 6.0$ containing different concentrations of $\mathrm{F}^{-}\left(1,5,10,20,50,80,100 \mathrm{mg} \mathrm{L}^{-1}\right)$. To examine the possible aging effect of the FAC gels, DGT devices preloaded with the tri-metal adsorbent were stored in $0.01 \mathrm{~mol} \mathrm{~L}^{-1} \mathrm{NaNO}_{3}$ for $1,20,36,60$, and $105 \mathrm{~d}$ after production at $4{ }^{\circ} \mathrm{C}$. Thereafter they were deployed for $4 \mathrm{~h}$ in $2 \mathrm{~L}$ of solutions containing $1 \mathrm{mg} \mathrm{L}^{-1} \mathrm{~F}^{-}$and $0.01 \mathrm{~mol} \mathrm{~L}^{-1} \mathrm{NaNO}_{3}$.

2.7. Demonstration and validation of FAC-DGT samplers in surface water systems.

Field Deployment-1: Freshwater River. In order to test the applicability of the FAC-DGT in natural water, DGT devices were used to measure $\mathrm{F}^{-}$in the Jiuxiang River, a freshwater river located in Nanjing city, China. The basic parameters of the river water are listed in Table S1. The site was specifically selected because of its characteristic alkaline conditions, a feature of many $\mathrm{F}^{-}$enriched waters. Six DGT 
devices were assembled as a hexahedral unit, leaving the exposure windows facing outwards (Pan et al., 2015; Zheng et al., 2015), and bound with button thermometers (Maxim Integrated Products, USA) to record temperature every $1 \mathrm{~h}$, the hexahedral unit was immersed in the river water and retrieved after 5 days. Water samples were collected at 10 am and $4 \mathrm{pm}$ every day to monitor the concentration of $\mathrm{F}^{-}$in the river water. The water samples were taken to the laboratory within 10 min after sampling, passed through $0.45-\mu \mathrm{m}$ membrane filters and stored at $4^{\circ} \mathrm{C}$ prior to measurement.

Field Deployment-2: F-containing wastewater. To investigate the FAC-DGT in waters severely enriched with $\mathrm{F}^{-}$, an assembled hexahedral unit of DGT devices with button thermometers was immersed into a wastewater with a $\mathrm{F}^{-}$concentration of $\sim 12$ $\mathrm{mg} \mathrm{L}^{-1}$. However, to compensate for the atypically solute/ion enriched water matrix, the DGT devices were only immersed in the wastewaters for a maximum of $17 \mathrm{~h}$. Water samples were collected six times during $17 \mathrm{~h}$.

\subsection{Application of the FAC-DGT in sediments of Lake Luoma}

To ascertain the role of a sediment as either a sink or source of $\mathrm{F}^{-}$, the contrasting concentration gradients and deduced fluxes from sediment-water interfaces (SWI) can only be quantitatively interpreted if measurements are obtained in situ and at sufficiently high spatial resolutions (Harper et al., 1997). To test the ability of the new FAC-DGT to capture these chemistries, deployments of the samplers in probe configurations (Davison et al., 1997) were tested in sediment cores from Lake Luoma, South Eastern China (see: Fig. 1, sampling details are described in the SM). The lake was selected principally because of recent water quality concerns due to increasing $\mathrm{F}^{-}$ 
concentrations. The underlying cause of the enrichment of the waterbody was thought to have stemmed from disturbances caused by the extensive sand excavation activities in the lake, driven by the demand for building materials. In addition to the importance of the site as a reservoir for drinking waters, it is of strategic value as an intersection of the Huaihe River (one of the seven major rivers in China) (Wen et al., 2013) and conduit for the South-to-North Water Diversion megaproject (Fig. 1); a national scheme that aims to deliver water to the drought prone regions in Northern China, by redirecting supplies from the southern watersheds (Liang et al., 2012).

In brief, three contrasting sediment sites, both in regards to spatial location, particle size distribution and stratification characteristics, within the lake were selected for deployment. Each site was approximately $20 \mathrm{~km}$ away from the other, but each had surface-water F concentrations above $1 \mathrm{mg} \mathrm{L}^{-1}$ (Table S2, see SM). Site A, on the lakes western flank was a silty-clay sediment, overlain by a 7-cm thick sand cap. The profile of Site B, was homogenously sandy in texture, whereas Site C, was dominated by silty, fine particulates (Fig. 1).

FAC-DGT probes, consisting of a plastic backing plate, a FAC gel layer, a 0.8-mm diffusive gel layer, a 0.14-mm filter membrane and a front plate with a $1.8 \times$ $15 \mathrm{~cm}$ exposure window (Harper et al., 1998) were inserted vertically into the lake bed traversing both the SWI and any sediment stratification features (i.e. sand-silt interface, SSI). After $24 \mathrm{~h}$ deployment, the probes were retrieved and the window areas were thoroughly rinsed with MQ water. The exposed gel layers and filters were cut from the probe housing using a Teflon-coated razor blade (Guan et al., 2015). The 
FAC gel and diffusive gel were both sliced into $0.6 \times 0.5 \mathrm{~cm}$ rectangles (every piece of gel was divided into three vertical columns/strips, corresponding to the horizontal position $0-0.6,0.6-1.2$ and $1.2-1.8 \mathrm{~cm}$, with each column comprising of thirty $0.6 \times$ $0.5 \mathrm{~cm}$ rectangular sections). Each FAC gel and diffusive gel sample was then placed into individual $1 \mathrm{~mL}$ centrifuge tubes containing $0.3 \mathrm{~mL}$ of $0.1 \mathrm{~mol} \mathrm{~L}^{-1} \mathrm{NaOH}$ solution and $0.2 \mathrm{~mL}$ of $1 \mathrm{~mol} \mathrm{~L}^{-1} \mathrm{HNO}_{3}$ respectively. After at least $24 \mathrm{~h}$, the elution samples were diluted, then analysed by the SPADNS-Vis-S method for $\mathrm{F}^{-}$and ICP-OES (Optima 5300DV, PerkinElmer, USA) for other metals.

To determine lacustrine storage mechanisms, the apparent fluxes of $\mathrm{F}^{-}$across the interface zones, SWI and SSI, were calculated using a numerical model (Roberts et al., 2010) based on sediment properties following Eqs. 3, 4 and 5, to

$$
\begin{aligned}
& F_{w}=D_{w} \times(-)_{(\mathrm{x}=0)} \\
& F_{s}=D_{s} \times(-) \\
& F_{\text {total }}=F_{w}+F_{s}
\end{aligned}
$$

$F_{\text {total }}$ refers to the total flux of $\mathrm{F}^{-}$across the interface, while $F_{w}$ and $F_{s}$ represent the fluxes of $\mathrm{F}^{-}$across the SWI from the overlying water and from the sediment, respectively. $\left({ }_{(\mathrm{C}=0)}\right.$ and $(-)_{(\mathrm{x}=0)}$ are the DGT measured concentration gradients in the overlying water and sediment, respectively. $D_{w}$ and $D_{s}$ are the diffusion coefficients of $\mathrm{F}^{-}$in water and sediment (Ullman and Aller, 1982).

\section{Result and discussion}

\section{1. efficiency (fe) of FAC gels}

A DGT-elution procedure that removes the majority of the immobilized target analyte, 
with reproducible efficiency is a prerequisite for DGT measurements (Davision and Zhang, 1994). It is documented that $\mathrm{NaOH}$ is an efficient elution solution to desorb $\mathrm{F}^{-}$ from adsorbents (Paudyal et al., 2012; Zhang et al., 2005; Zhou et al., 2004) used in wastewater treatment. In this study, different strengths of $\mathrm{NaOH}(0.1,0.5$, and $1.0 \mathrm{~mol}$ $\mathrm{L}^{-1}$ ) were used to elute $\mathrm{F}^{-}$from the binding gels. Furthermore, the $f_{\mathrm{e}}$ values for FAC gels with different mass loadings of $\mathrm{F}^{-}$were also measured. As shown in Table 1, consistent elution efficiencies $\left(f_{\mathrm{e}}=\sim 0.8\right)$ were obtained using different concentrations of $\mathrm{NaOH}$ as an eluent for a wide range of $\mathrm{F}^{-}$concentrations $\left(10,50\right.$ or $200 \mu \mathrm{g} \mathrm{F}^{-}$on each gel disc), indicating that elution efficiencies are high and consistent. Given that the $\mathrm{pH}$ of eluates needs to be adjusted to an acid condition with $\mathrm{HCl}$ before measurement using the SPADNS method, $0.1 \mathrm{~mol} \mathrm{~L}^{-1} \mathrm{NaOH}$ was finally selected as the preferred $\mathrm{F}^{-}$-eluent to minimize the acid requirements for the chemical analysis.

\section{2. coefficient $(D)$ in the diffusive gel}

Measurement of the diffusion coefficient of $\mathrm{F}^{-}$is necessary to analyze $\mathrm{F}^{-}$in waters correctly using the DGT technique. Due to the lack of published $D$-values for $\mathrm{F}^{-}$in DGT diffusive gels, measurements were conducted using two established methods, diffusion cell ( $\left.D_{\text {cell }}\right)$ (Zhang et al., 1998c) and DGT device deployment $\left(D_{\text {DGT }}\right)$ (Zhang et al., 1998a). The value of $D_{\text {cell }}$ was $1.04 \times 10^{-5} \mathrm{~cm}^{2} \mathrm{~s}^{-1}$, derived from Fig. S2 using Eq. S6, which has been corrected from $19^{\circ} \mathrm{C}$ (solution temperature in experiments) to $25^{\circ} \mathrm{C}$ with a temperature-based conversion equation (Zhang and Davison, 1995). Compared with the value of $D_{\text {DGT }}\left(9.75 \times 10^{-6} \mathrm{~cm}^{2} \mathrm{~s}^{-1}\right.$, calculated from Eq. 2$)$, there was no apparent difference between the two approaches with a bias of less than 5\%, 
which indicates that the diffusive boundary layer (DBL) between the diffusive gel and surface solution (Bennett et al., 2010) can be neglected. Consistent results between the two methods have been previously reported when measuring $D$-values for oxyanions such as those formed by P, V, As, Se, Sb, and Mo (Guan et al., 2015; Luo et al., 2010; Zhang et al., 1998b).

Previous investigations of diffusion coefficients in diffusive gels show that the greater impedance forces incurred by polyacrylamide gel matrixes compared with water results in the $D$-value of metal ions in DGT diffusive gels being $\sim 85 \%$ of those in aqueous solution (Scally et al., 2006), while for oxyanions (P, As, Se, Sb, and V), the difference is more pronounced with a typical decrease in the range of $52-71 \%$ depending on species (Luo et al., 2010; Panther et al., 2008; Sogn et al., 2008). The $D$ of $\mathrm{F}^{-}$at $25^{\circ} \mathrm{C}$ measured using a diffusive cell is $\sim 71 \%$ of the value in water $\left(1.48 \times 10^{-5}\right.$ $\mathrm{cm}^{2} \mathrm{~s}^{-1}$ ) reported by Buffle et al. (Buffle et al., 2007). Furthermore, there is no measurable charge effect, Donnan partitioning, or specific binding for anions if diffusive gels are well washed (Luo et al., 2010).

\subsection{Ionic strength, $\mathrm{pH}$ and deployment time}

As shown in Fig. 2A, the ratio, $R$, of the concentration of $\mathrm{F}^{-}$measured by DGT, $C_{\mathrm{DGT}}$, to that in solution, $C_{\text {soln }}$, is highly reproducible within a wide range of $\mathrm{NaNO}_{3}$ concentrations. $R$ values were within an acceptable range for $\mathrm{NO}_{3}{ }^{-}$concentrations between 100-200 mmol L ${ }^{-1}$, but were excellent between 0-100 $\mathrm{mmol} \mathrm{L}^{-1}$. Since the ionic strength in fresh and most waste-waters is lower than $100 \mathrm{mmol} \mathrm{L}^{-1}$ (Glass and Silverstein, 1999; Turner et al., 1981), FAC-DGT can effectively measure $\mathrm{F}^{-}$in these 
water bodies. However, as the ionic strength of seawater is $\sim 700 \mathrm{mmol} \mathrm{L}{ }^{-1}$, the technique is not appropriate for saline water deployments.

F- $C_{\text {DGT }}$ values agreed well ( $R$ values, $0.9-1.1$, Fig. $\left.2 \mathrm{~B}\right)$ with $\mathrm{F}^{-}$concentration in solutions within the $\mathrm{pH}$ range of 4.3-9.1. But $R$ values at $\mathrm{pH} 3.15$ were below 0.8 . At pH lower than 3.45 , more than $50 \%$ of the $\mathrm{F}^{-}$in solution exists as HF (Ghosh et al., 2013). As HF has a lower $D$-value than $\mathrm{F}^{-}$, a correction to the $\mathrm{F}-C_{\mathrm{DGT}}$ calculation to compensate for this may be required. Additionally, the surface of the FAC oxides mixture is positively charged at $\mathrm{pH} 3.15$, so the binding of neutrally charged $\mathrm{F}$ species (HF, $\mathrm{NaF}$ etc.) is expected to be weak. The excellent $R$ values recorded for a wide $\mathrm{pH}$ range (4 to 9) shows a good application prospect of FAC-DGT in acidic to alkaline waters.

The measured mass of $\mathrm{F}^{-}$accumulated by FAC-DGT increased linearly, i.e, steady-state conditions were never obtained, within deployment times up to $72 \mathrm{~h}$ (Fig. 2C) and agreed well with the theoretical values calculated from the known solution concentrations using Eq. 2.

\subsection{Capacity of DGT and aging effect}

The measured mass of $\mathrm{F}^{-}$accumulated by FAC-DGT increased linearly with the solution concentrations ranging from 1 to $80 \mathrm{mg} \mathrm{L}^{-1}$ as shown in Fig. 2D, fitting the theoretical calculated values (Eq. 2). This demonstrated that the capacity of FAC-DGT was not exceeded until the concentration of $\mathrm{F}^{-}$in solutions reached $100 \mathrm{mg}$ $\mathrm{L}^{-1}$, indicating that the capacity of the binding gel is $247 \pm 21 \mu \mathrm{g}$ per gel disc $(98 \pm 8$ $\mu \mathrm{g} \mathrm{cm}^{-2}$ ). In practical terms this means, FAC-DGT can be deployed for at least $9 \mathrm{~d}$ in 
waters containing $1.5 \mathrm{mg} \mathrm{L}^{-1} \mathrm{~F}^{-}$, calculated from Eq. 2, without exceeding the sampler's capacity. If $\mathrm{F}^{-}$elevated waters are being sampled, thicker diffusive gels, shorter deployment time and a higher loading of FAC oxides mixture into binding gels are simple adjustments to the DGT to make it suitable for monitoring highly-polluted water.

The performance characteristics of DGT containing FAC gel, stored in $0.01 \mathrm{~mol}$ $\mathrm{L}^{-1} \mathrm{NaNO}_{3}$ for $1-105 \mathrm{~d}$ from production, to evaluate possible degradation/integrity of the binding gels during storage, are shown in Fig. S6. The measurement of $\mathrm{F}^{-}$by DGT devices agreed well with solution concentrations, with the $R$ value between 0.9 and 1.1 within $36 \mathrm{~d}$ while there was a little decline of $R$ value of $0.89 \pm 0.06$ after $60 \mathrm{~d}$ and $0.88 \pm 0.06$ after $105 \mathrm{~d}$, which were within acceptable range. Therefore, DGT devices are suitable for both long-term storage and long-time deployment.

\subsection{In Situ monitoring of $F$ in a freshwater river and $F^{-}$-containing wastewater}

In this experiment (field deployment-1), $\mathrm{F}^{-}$concentrations in the Jiuxiang River, were determined using both active sampling and FAC-DGT methods. The different concentrations of $\mathrm{F}^{-}$in the river acquired by active sampling from 10 am in day 1 to 4 pm in day 5 are shown in Fig. 3, which were comparable to other rivers like the Huaihe River (0.2-3.1 mg L $\left.{ }^{-1}\right)$ in China (Wen et al., 2013), and the Humber Rivers (0.05-3.38 $\left.\mathrm{mg} \mathrm{L}^{-1}\right)$ in the UK (Neal et al., 2003). The averaged DGT concentrations of $\mathrm{F}^{-}$(represented as solid black line, Fig. 3) are close to the averaged concentrations measured by active sampling (solid blue line), which demonstrates the averaged values provided by DGT could substitute for high frequency grab sampling, especially 
when the $\mathrm{F}^{-}$concentrations are highly variable.

To investigate the applicability of FAC-DGT in a highly polluted aquatic matrix with high ion loading and severe $\mathrm{F}^{-}$enrichment, further deployment of the FAC-DGT devices were performed in a wastewater treatment flume pond (field deployment-2). The basic parameters of the wastewater are listed in Table S1. Again like field deployment-1, the waters possessed a high $\mathrm{pH}$ value (9.0). Concentrations of $\mathrm{F}$, fluctuating within the deployment period $(17 \mathrm{~h})$, caused by the addition of water treatment agents (mainly lime), were detected by an active sampling method and the FAC-DGT approach (Fig. 3). Lime $\left(\mathrm{CaO}\right.$ or $\left.\mathrm{Ca}(\mathrm{OH})_{2}\right)$ precipitation was used as part of a tertiary process of phosphate and nitrogen removal. Therefore, free ion concentrations of $\mathrm{F}^{-}$in the wastewater treatment pond, would have declined as $\mathrm{CaF}^{+}$ complexes formed (Ayoob and Gupta, 2006; Jha et al., 2011). Different $D$-values between the species, coupled with the ion's positive surface charge, all contribute to the slightly separation between the averaged $\mathrm{F}^{-}$concentrations measured by DGT (black line, Fig. 3) and that by active sampling (blue line, Fig. 3), leading to the decreased $R$ value of 0.82 . However these were still within acceptable operational parameters for the samplers and suggest a correction factor to compensate for species changes would be warranted.

\subsection{In Situ profiling of sediments in Lake Luoma}

Porewater solute measurements, including $\mathrm{F}^{-}$, from sediment core samples are commonly obtained by slicing and centrifugation to isolate the target analytes (Kjeller and Rappe, 1995; Stockdale et al., 2010). Yet, this provides little information on the 
system's ability to either entrain/remove or supply $\mathrm{F}^{-}$to the overlying water column; data that is key to the successful management of a site. Fine scale measurements of $\mathrm{F}^{-}$ mobilization patterns in three contrasting lake sediments (Table S2), demonstrate the use of the new DGT platform for modeling net $\mathrm{F}^{-}$fluxes between matrix compartment interfaces, within the sediment (sand-silt stratification) or with between sediments and overlying water.

DGT uncovered a number of different biogeochemical $\mathrm{F}^{-}$mobilization trends in the sediment media based on the calculated net fluxes (Table 2). PA from site A (Fig. 4), indicates that the sand cap (between SWI and SSI) overlying the silt sediment is likely to be acting as a marginal sink for $\mathrm{F}^{-}$, with a small flux of $0.7 \times 10^{-6} \mu \mathrm{g} \mathrm{cm}^{-2} \mathrm{~s}^{-1}$ from water to sand. The high Si content (\%, Table S2, SM) of this zone would also facilitate $\mathrm{F}^{-}$immobilization (Vithanage and Bhattacharya, 2015). However, its long-term function as a $\mathrm{F}^{-}$reservoir is becoming compromised by the underlying silty sediment zone (under SSI), which is supplying $\mathrm{F}^{-}$to the sandy cap, at a rate of $1.3 \times$ $10^{-6} \mu \mathrm{g} \mathrm{cm}^{-2} \mathrm{~s}^{-1}$. If the two sediment materials reach equilibrium, then the role of the SWI in helping to reduce water column $\mathrm{F}^{-}$concentrations could be reversed. The surface water $\mathrm{F}^{-}$concentrations at site $\mathrm{B}$ (PB, Fig. 4), are the most $\mathrm{F}^{-}$enriched, averaging $0.8 \mathrm{mg} \mathrm{L}^{-1}$. Similarly to Site A, the sediment PB which is uniformly sandy,

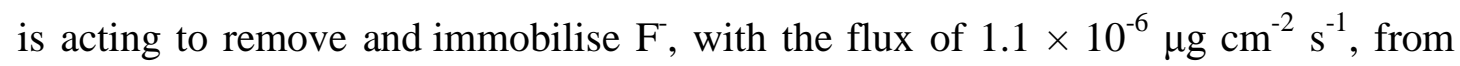
water to sand. However, the average $\mathrm{F}^{-}$mobilisation flux is slightly higher than that of the representative zone from site A and also relatively constant even to the depth of $-12 \mathrm{~cm}$ below the SWI. The SSI is in approximate equilibrium with the overlying 
water in PC, based on the average measurements for the two matrix compartments (water/sediment).

Correlations were undertaken to test the coexistence of $\mathrm{F}^{-}$with metals in the three sediments (PA, PB and PC) (Table S3). Close correlations between $\mathrm{F}^{-}$and $\mathrm{Al} / \mathrm{Mn}$ emerged in all three matrices, and further, similar correlations between $\mathrm{F}^{-}$and $\mathrm{Al} / \mathrm{Mn}$ (sum of concentrations) in PA, PB and PC $(r=0.51-0.53, p<0.01)$ emerged. These trends that are indicative of $\mathrm{F}^{-}$mobilization being coupled with the reductive remobilization of $\mathrm{Al}$, Mn hydroxides containing $\mathrm{F}^{-}$(Lv et al., 2006; Wemple et al., 1995).

\section{Conclusions}

The new tri-metal FAC-DGT gel is superior to other potential $\mathrm{F}^{-}$-adsorbents due to the broad $\mathrm{pH}$ ranges 4.3-9.1 in which it operates, with the ability to function in low $\mathrm{H}^{+}$ concentrations being of specific importance for environmental $\mathrm{F}^{-}$monitoring. Furthermore, the DGT method detection limits were 4 -fold lower than common solution analysis using colorimetric techniques, combined with its high capacity (98 \pm $8 \mu \mathrm{g} \mathrm{cm}{ }^{-2}$ ), long term stability (>105 $\mathrm{d}$ after gel fabrication) and resilience to competitive ions, all makes it suitable for use in a wide range of matrixes, which include rivers, waste waters, synthetic solutions, sediments and wetland soils.

It is arid zones, where safe-water resources are already limited, that $\mathrm{F}^{-}$-contamination is most severe and consequently more difficult to tackle. In China alone, more than 40 million people rely on drinking waters which are threatened by $\mathrm{F}^{-}$ contamination (Wen et al., 2013). On a global scale, there are also significant $\mathrm{F}^{-}$water 
quality problems in India, Tanzania, Mexico, Argentina, and South Africa. Often contaminated water supplies are in rural areas, so convenient and easy-to-operate methods are especially needed (Vithanage and Bhattacharya, 2015). The presented FAC-DGT offers a simple and cost effective way for households to monitor their potential $\mathrm{F}^{-}$-exposures. While, for the researchers/chemists the FAC-DGT can be employed to understand fine-scale mobilization processes occurring at the mineral/soil/sediment-water interfaces, in either 1 or 2D. The FAC-DGT technique when used in combination with the SPADNS spectrophotometer method, is very well suited for in situ deployment in waters and sediments especially in remote and poorly accessible areas, presenting a new opportunity for time-integrated measurements to better understand $\mathrm{F}^{-}$-cycling for both environmental and human health risk assessment.

\section{Acknowledgements}

This work was supported by the National Science Foundation of China (No. 21477053), the Specialized Research Fund for the Doctoral Program of Higher Education, Ministry of Education of China (20120091120016), the Fundamental Research Funds for the Central Universities (021114380020) and the program B for Outstanding $\mathrm{PhD}$ candidate of Nanjing University. The study also received support from the Newton Fund/Royal Society and NFSC (R1504GFS and 21511130063).

Appendix A. Supplementary data Equations; Preparation of diffusive gels; Preparation of SPADNS initial solution, $\mathrm{ZrOCl}_{2} \cdot 8 \mathrm{H}_{2} \mathrm{O}$ solution and SPADNS solution; 
459 DGT blank and method detection limit; Binding kinetic; Measurement and calculation 460 of diffusion coefficient (D); Assessment of possible adsorption of $\mathrm{F}^{-}$by diffusive gel 461 and filter membrane; Effect of diffusive gel thickness and competition of $\mathrm{Cl}^{-}$and $462 \mathrm{SO}_{4}{ }^{2-}$ on DGT uptake; Sediments sampling and pretreatment.

463

464 
Amini, M., Mueller, K., Abbaspour, K.C., Rosenberg, T., Afyuni, M., Møller, K.N., Sarr, M. and Johnson, C.A., 2008. Statistical modeling of global geogenic fluoride contamination in groundwaters. Environ. Sci. Technol. 42 (10), 3662-3668. Ayoob, S. and Gupta, A.K., 2006. Fluoride in drinking water: a review on the status and stress effects. Crit. Rev. Environ. Sci. Technol. 36 (6), 433-487. Bennett, W.W., Teasdale, P.R., Panther, J.G., Welsh, D.T. and Jolley, D.F., 2010. New diffusive gradients in a thin film technique for measuring inorganic arsenic and selenium (IV) using a titanium dioxide based adsorbent. Anal. Chem. 82 (17), 7401-7407.

Buffle, J., Zhang, Z. and Startchev, K., 2007. Metal flux and dynamic speciation at (Bio)interfaces. Part I: critical evaluation and compilation of physicochemical parameters for complexes with simple ligands and Fulvic/Humic substances. Environ. Sci. Technol. 41 (22), 7609-7620. Das, D.P., Das, J. and Parida, K., 2003. Physicochemical characterization and adsorption behavior of calcined $\mathrm{Zn} / \mathrm{Al}$ hydrotalcite-like compound (HTlc) towards removal of fluoride from aqueous solution. J. Colloid Interf. Sci. 261 (2), 213-220.

Davision, W. and Zhang, H., 1994. In situ speciation measurements of trace components in natural waters using thin-film gels. Nature 367 546-548.

Davison, W., Fones, G.R. and Grime, G.W., 1997. Dissolved metals in surface sediment and a microbial mat at $100-\mu \mathrm{m}$ resolution. Nature 387 885-888.

Fawell, J., Bailey, K., Chilton, J., Dahi, E., Fewtrell, L. and Magara, Y., 2006. Fluoride in drinking-water. WHO 47.

Gao, Y., Canck, E.D., Leermakers, M., Baeyens, W. and Voort, P.V.D., 2011. Synthesized mercaptopropyl nanoporous resins in DGT probes for determining dissolved mercury concentrations. Talanta 87 262-267.

Ghosh, A., Mukherjee, K., Ghosh, S.K. and Saha, B., 2013. Sources and toxicity of fluoride in the environment. Res. Chem. Intermediat. 39 (7), 2881-2915. Glass, C. and Silverstein, J., 1999. Denitrification of high-nitrate, high-salinity wastewater. Water Res.

Guan, D.X., Williams, P.N., Luo, J., Zheng, J.L., Xu, H.C., Cai, C. and Ma, L.Q., 2015. Novel precipitated zirconia-based DGT technique for high resolution imaging of oxyanions in waters and sediments. Environ. Sci. Technol. 49 (6), 3653-3661.

Harper, M.P., Davison, W. and Tych, W., 1997. Temporal, spatial, and resolution constraints for in situ sampling devices using diffusional equilibration: dialysis and DET. Environ. Sci. Technol. 31 (11), 3110-3119.

Harper, M.P., Davison, W., Zhang, H. and Tych, W., 1998. Kinetics of metal exchange between solids and solutions in sediments and soils interpreted from DGT measured fluxes. Geochim. Cosmochim. Ac. 62 (16), 2757-2770.

Harrison, P.T.C., 2005. Fluoride in water: a UK perspective. J. Fluorine Chem. 126 (11-12), 1448-1456. Hoop, M.A.G.T.v.d., Cleven, R.F.M.J., Staden, J.J.v. and Neele, J., 1996. Analysis of fluoride in rain water comparison of capillary electrophoresis with ion chromatography and ion-selective electrode potentiometry. J. Chromatogr. A 739 (1-2), 241-248.

Hu, S., Luo, T. and Jing, C., 2013. Principal component analysis of fluoride geochemistry of groundwater in Shanxi and Inner Mongolia, China. J. Geochem. Explor. 135 124-129. 
Jha, S.K., Mishra, V.K., Sharma, D.K. and Damodaran, T., 2011. Fluoride in the environment and its metabolism in humans. Rev. Environ. Contam. T. 211 121-142.

Kjeller, L.-O. and Rappe, C., 1995. Time trends in levels, patterns, and profiles for polychlorinated dibenzo-p-dioxins, dibenzofurans, and biphenyls in a sediment core from the baltic proper. Environ. Sci. Technol. 29 (2), 346-355.

Liang, Y.S., Wang, W., Li, H.J., Shen, X.H., Xu, Y.L. and Dai, J.R., 2012. The South-to-North Water Diversion Project: effect of the water diversion pattern on transmission of Oncomelania hupensis, the intermediate host of Schistosoma japonicum in China. Parasite. Vector. 5 (52),

Luo, J., Zhang, H., Santner, J. and Davison, W., 2010. Performance characteristics of diffusive gradients in thin films equipped with a binding gel layer containing precipitated ferrihydrite for measuring Arsenic(V), Selenium(VI), Vanadium(V), and Antimony(V). Anal. Chem. 82 (21), 8903-8909.

Lv, L., He, J., Wei, M., Evans, D.G. and Duan, X., 2006. Factors influencing the removal of fluoride from aqueous solution by calcined $\mathrm{Mg}-\mathrm{Al}-\mathrm{CO}_{3}$ layered double hydroxides. J. Hazard. Mater. 133 (1-3), 119-128.

Meenakshi and Maheshwari, R.C., 2006. Fluoride in drinking water and its removal. J. Hazard. Mater. 137 (1), 456-463.

Neal, C., Neal, M., Davies, H. and Smith, J., 2003. Fluoride in UK rivers. Sci. Total Environ. 314 209-231.

Pan, Y., Guan, D.X., Zhao, D., Luo, J., Zhang, H., Davison, W. and Ma, L.Q., 2015. Novel speciation method based on diffusive gradients in thin-films for in situ measurement of $\mathrm{Cr}^{\mathrm{VI}}$ in aquatic systems. Environ. Sci. Technol. 49 (24), 14267-14273.

Panther, J.G., Stillwell, K.P., Powell, K.J. and Downard, A.J., 2008. Development and application of the diffusive gradients in thin films technique for the measurement of total dissolved inorganic arsenic in waters. Anal. Chim. Acta 622 (1), 133-142.

Paudyal, H., Pangeni, B., Ghimire, K.N., Inoue, K., Ohto, K., Kawakita, H. and Alam, S., 2012. Adsorption behavior of orange waste gel for some rare earth ions and its application to the removal of fluoride from water. Chem. Eng. J. 195-196 (1), 289-296.

Perdikaki, K., Tsagkatakis, I., Chaniotakis, N.A., Altmann, R., Jurkschat, K. and Reeske, G., 2002. Selective fluoride recognition and potentiometric properties of ion-selective electrodes based on bis(halodiphenylstannyl)alkanes. Anal. Chim. Acta 467 (1-2), 197-204.

Perumal, E., Paul, V., Govindarajan, V. and Panneerselvam, L., 2013. A brief review on experimental fluorosis. Toxicol. Lett. 223 (2), 236-251.

Pillai, A.B., Varghese, B. and Madhusoodanan, K.N., 2012. Design and development of novel sensors for the determination of fluoride in Water. Environ. Sci. Technol. 46 (1), 404-409.

Roberts, L.C., Hug, S.J., Dittmar, J., Voegelin, A., Kretzschmar, R., Wehrli, B., Cirpka, O.A., Saha, G.C., Ali, M.A. and Badruzzaman, A.B.M., 2010. Arsenic release from paddy soils during monsoon flooding. Nat. Geosci. 3 53-59.

Santner, J., Prohaska, T., Luo, J. and Zhang, H., 2010. Ferrihydrite containing gel for chemical imaging of labile phosphate species in sediments and soils using diffusive gradients in thin films. Anal. Chem. 82 (18), 7668-7674.

Scally, S., Davison, W. and Zhang, H., 2006. Diffusion coefficients of metals and metal complexes in hydrogels used in diffusive gradients in thin films. Anal. Chim. Acta 558 (1-2), 222-229.

Severi, M., Becagli, S., Frosini, D., Marconi, M., Traversi, R. and Udisti, R., 2014. A novel fast ion 
chromtographic method for the analysis of fluoride in antarctic snow and ice. Environ. Sci. Technol. 48 (3), 1795-1802.

Sogn, T.A., Eich-Greatorex, S., Røyset, O., Øgaard, A.F. and Almås, Å.R., 2008. Use of diffusive gradients in thin films to predict potentially bioavailable selenium in soil. Commun. Soil Sci. Plan. 39 (3), 587-602.

Stockdale, A., Davision, W. and Zhang, H., 2010. 2D simultaneous measurement of the oxyanions of P, V, As, Mo, Sb, W and U. J. Environ. Monit. 12 981-984.

Stockdale, A., Davison, W. and Zhang, H., 2008. High-resolution two-dimensional quantitative analysis of phosphorus, vanadium and arsenic, and qualitative analysis of sulfide, in a freshwater sediment. Environ. Chem. 5 (2), 143-149.

Su, C., Wang, Y., Xie, X. and Li, J., 2013. Aqueous geochemistry of high-fluoride groundwater in Datong Basin, Northern China. J. Geochem. Explor. 135 79-92.

Sun, J.F., Liu, R., Zhang, Z.M. and Liu, J.F., 2014. Incorporation of the fluoride induced Si-O bond cleavage and functionalized gold nanoparticle aggregation into one colorimetric probe for highly specific and sensitive detection of fluoride. Anal. Chim. Acta 820 139-145.

Tokunaga, S., Hardon, M.J. and Wasay, S.A., 1995. Removal of fluoride ions from aqueous solution by multivalent metal compounds. Int. J. Environ. Stud. 48 (1), 17-28.

Turner, D.R., Whitfield, M. and Dickson, A.G., 1981. The equilibrium speciation of dissolved components in freshwater and sea water at $25^{\circ} \mathrm{C}$ and 1 atm pressure. Geochim. Cosmochim. Ac. 45 (6), 855-881.

Ullman, W.J. and Aller, R.C., 1982. Diffusion coefficient in nearshore marine sediments. Limnol. Oceanogr. 27 (3), 552-556.

Viswanathan, G., Jaswanth, A., Gopalakrishnan, S., ilango, S.S. and Aditya, G., 2009. Determining the optimal fluoride concentration in drinking water for fluoride endemic regions in South India. Sci. Total Environ. 407 (20), 5298-5307.

Vithanage, M. and Bhattacharya, P., 2015. Fluoride in the environment: sources, distribution and defluoridation. Environ. Chem. Lett. 13 (2), 131-147.

Vrana, B., Mills, G.A., Allan, I.J., Dominiak, E., Svensson, K., Knutsson, J., Morrison, G. and Greenwood, R., 2005. Passive sampling techniques for monitoring pollutants in water. TrAC. Trends Anal. Chem. 24 (10), 845-868.

Warnken, K.W., Zhang, H. and Davison, W., 2005. Trace metal measurements in Low ionic strength synthetic solutions by diffusive gradients in thin films. Anal. Chem. 77 (17), 5440-5446.

Wemple, M.W., Adams, D.M., Folting, K., Hendrickson, D.N. and Christou, G., 1995. Incorporation of fluoride into a tetranuclear $\mathrm{Mn} / \mathrm{O} / \mathrm{RCO}_{2}$ aggregate: potential relevance to inhibition by fluoride of photosynthetic water oxidation. J. Am. Chem. Soc. 117 (27), 7275-7276.

Wen, D.G., Zhang, F.C., Zhang, E.Y., Wang, C., Han, S.B. and Zheng, Y., 2013. Arsenic, fluoride and iodine in groundwater of China. J. Geochem. Explor. 135 1-21.

Wu, X.M., Zhang, Y., Dou, X.M. and Yang, M., 2007. Fluoride removal performance of a novel Fe-Al-Ce trimetal oxide adsorbent. Chemosphere 69 (11), 1758-1764.

Zeng, Q. and Stebbins, J.F., 2000. Fluoride sites in aluminosilicate glasses: high-resolution 19F NMR results. Am. Mineral. 85 (5-6), 863-867.

Zhang, H. and Davision, W., 1999. Diffusional characteristics of hydrogels used in DGT and DET techniques. Anal. Chim. Acta 398 (2-3), 329-340.

Zhang, H., Davision, W., Gadib, R. and Kobayashia, T., 1998a. In situ measurement of dissolved 
phosphorus in natural waters using DGT. Anal. Chim. Acta 370 (1), 29-38.

Zhang, H. and Davison, W., 1995. Performance characteristics of diffusionin gradients in thin films for the in situ measurement of trace metals in aqueous solution. Anal. Chem. 67 (19), 3391-3400.

Zhang, H., Davison, W., Gadi, R. and Kobayashi, T., 1998b. In situ measurement of dissolved phosphorus in natural waters using DGT. Anal. Chim. Acta 370 (1), 29-38.

Zhang, H., Davison, W., Knight, B. and McGrath, S., 1998c. In situ measurements of solution concentrations and fluxes of trace metals in soils using DGT. Environ. Sci. Technol. 32 (5), 704-710.

Zhang, Y., Yang, M., Dou, X.M., He, H. and Wang, D.S., 2005. Arsenate adsorption on an Fe-Ce bimetal oxide adsorbent: role of surface properties. Environ. Sci. Technol. 39 (18), 7246-7253.

Zheng, J.L., Guan, D.X., Luo, J., Zhang, H., Davision, W., Cui, X.Y., Wang, L.H. and Ma, L.Q., 2015. Activated charcoal based diffusive gradients in thin films for in situ monitoring of bisphenols in waters. Anal. Chem. 87 (1), 801-807.

Zhou, Y.M., Yu, C.X. and Shan, Y., 2004. Adsorption of fluoride from aqueous solution on $\mathrm{La}^{3+}$ impregnated cross-linked gelatin. Sep. Purif. Technol. 36 (2), 89-94.

Zhu, C.Q., Chen, J.L., Zheng, H., Wu, Y.Q. and Xu, J.G., 2005. A colorimetric method for fluoride determination in aqueous samples based on the hydroxyl deprotection reaction of a cyanine dye. Anal. Chim. Acta 539 (1-2), 311-316. 


\section{Table 1}

Elution efficiency $\left(f_{\mathrm{e}}\right)$ of $\mathrm{F}^{-}$from the FAC gels using $3 \mathrm{~mL}$ of different concentrations $\left(0.1,0.5\right.$ and $\left.1.0 \mathrm{~mol} \mathrm{~L}^{-1}\right)$ of $\mathrm{NaOH}$ solution. Values were means \pm standard errors of five replicates.

\begin{tabular}{llll}
\hline $\begin{array}{l}\text { Mass of } \mathrm{F}^{-\mathrm{a}} \\
(\mu \mathrm{g} \text { per disc) }\end{array}$ & $0.1 \mathrm{~mol} \mathrm{~L}^{-1}$ & $0.5 \mathrm{~mol} \mathrm{~L}^{-1}$ & $1.0 \mathrm{~mol} \mathrm{~L}$ \\
\hline 10 & $0.81 \pm 0.05$ & $0.82 \pm 0.04$ & $0.80 \pm 0.05$ \\
50 & $0.78 \pm 0.02$ & $0.80 \pm 0.03$ & $0.79 \pm 0.01$ \\
200 & $0.82 \pm 0.03$ & $0.81 \pm 0.03$ & $0.81 \pm 0.02$ \\
\hline
\end{tabular}

${ }^{\mathrm{a}}$ denotes the mass of $\mathrm{F}^{-}$accumulated on the binding gels before elution. 
Table 2

Click here to download Table: Table 2.docx

\section{Table 2}

The total fluxes of $\mathrm{F}^{-}$across interface zones in sediment, '+' means the direction of flux is upward, while '-' means downward.

\begin{tabular}{llll}
\hline Flux $\left(10^{-6} \mu \mathrm{g} \mathrm{cm}^{-2} \mathrm{~s}^{-1}\right)$ & PA & PB & PC \\
\hline SWI & -0.7 & -1.1 & +0.2 \\
SSI & +1.3 & $/$ & $/$ \\
\hline
\end{tabular}




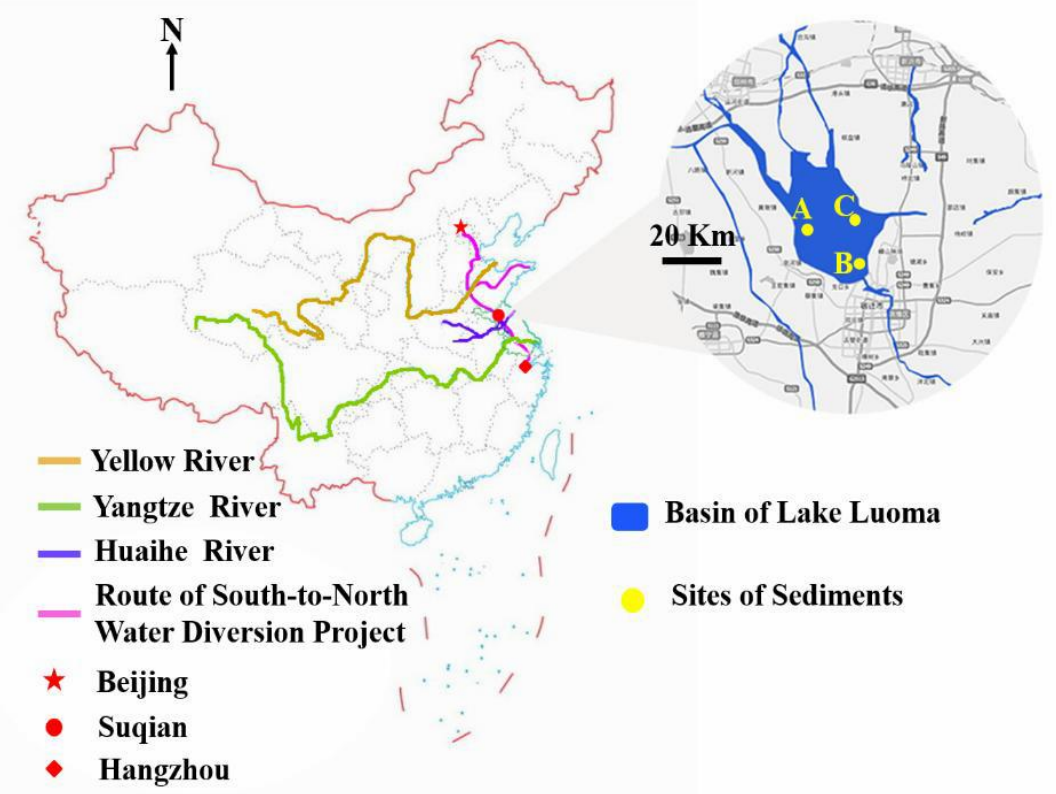

Fig. 1. The map provides the geographical position of Lake Luoma, located at the intersection of Huaihe River (one of the seven major rivers in China) and the Route of South-to-North Water Diversion Project (an important strategic project in China), and three sites of sediments (A, B and C) in Lake. 


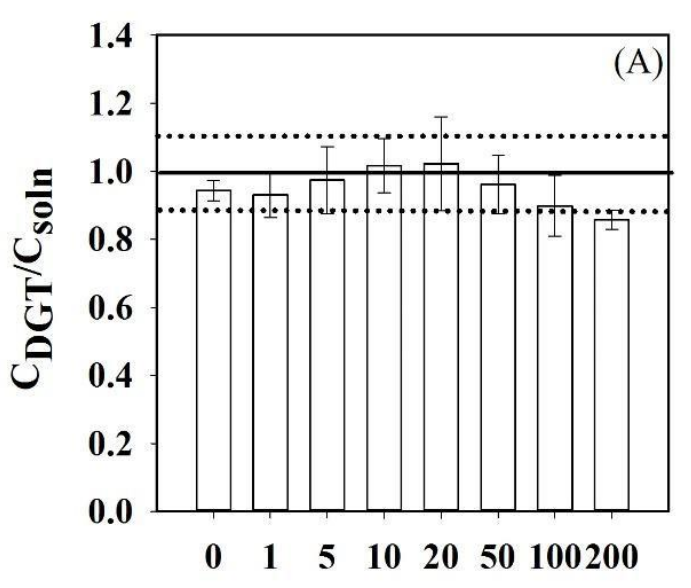

Concentration of $\mathrm{NO}_{3}^{-}\left(\mathrm{mmol} \mathrm{L}^{-1}\right)$

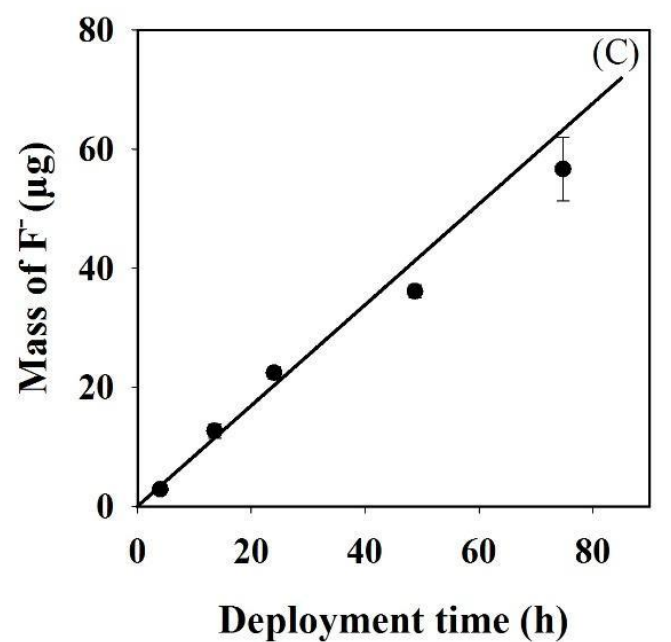

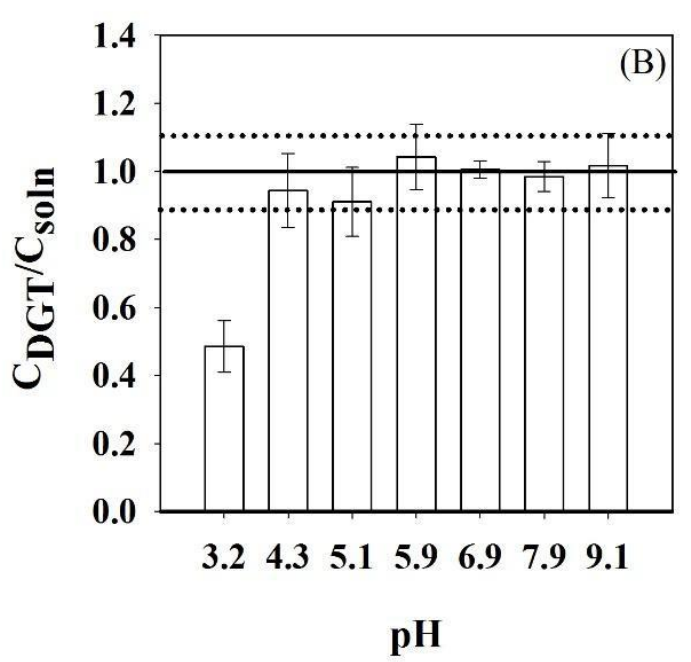

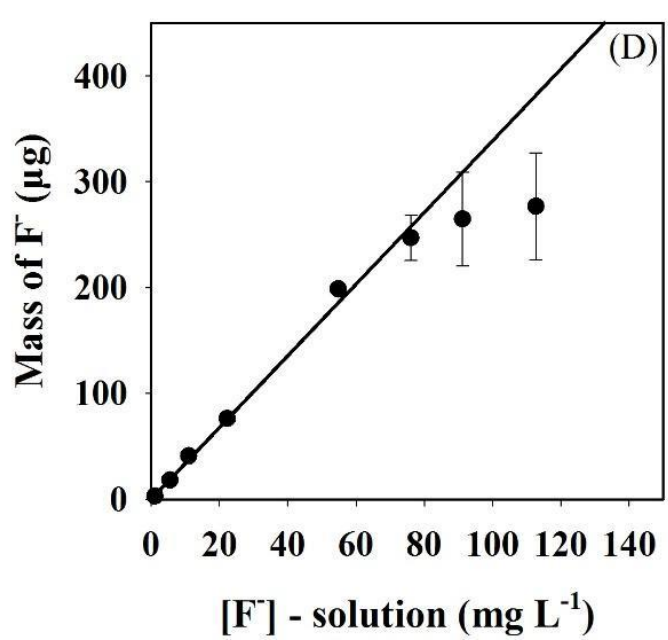

Fig. 2. The effects of ionic strength of $\mathrm{NO}_{3}{ }^{-}(\mathrm{A}), \mathrm{pH}(\mathrm{B})$ and deployment time (C) on the uptake of $\mathrm{F}^{-}$by FAC-DGT, and dependence of the mass of $\mathrm{F}^{-}$accumulated by DGT immersed in solutions with different concentrations of $\mathrm{F}^{-}$from 1 to $100 \mathrm{mg} \mathrm{L}^{-1}$ (D). The values of vertical axis in (A) and (B) mean the ratio of concentrations of $\mathrm{F}^{-}$ measured by DGT $\left(C_{\mathrm{DGT}}\right)$ to concentrations in solution $\left(C_{\text {soln }}\right)$ deployed with DGT. The dotted horizontal lines and the solid horizontal lines represented values of $1.0 \pm$ 0.1. In (C) and (D), the black lines are the theoretical lines calculated from known concentrations in solutions by Eq. 2 . Values are means \pm SD of three replicates. 

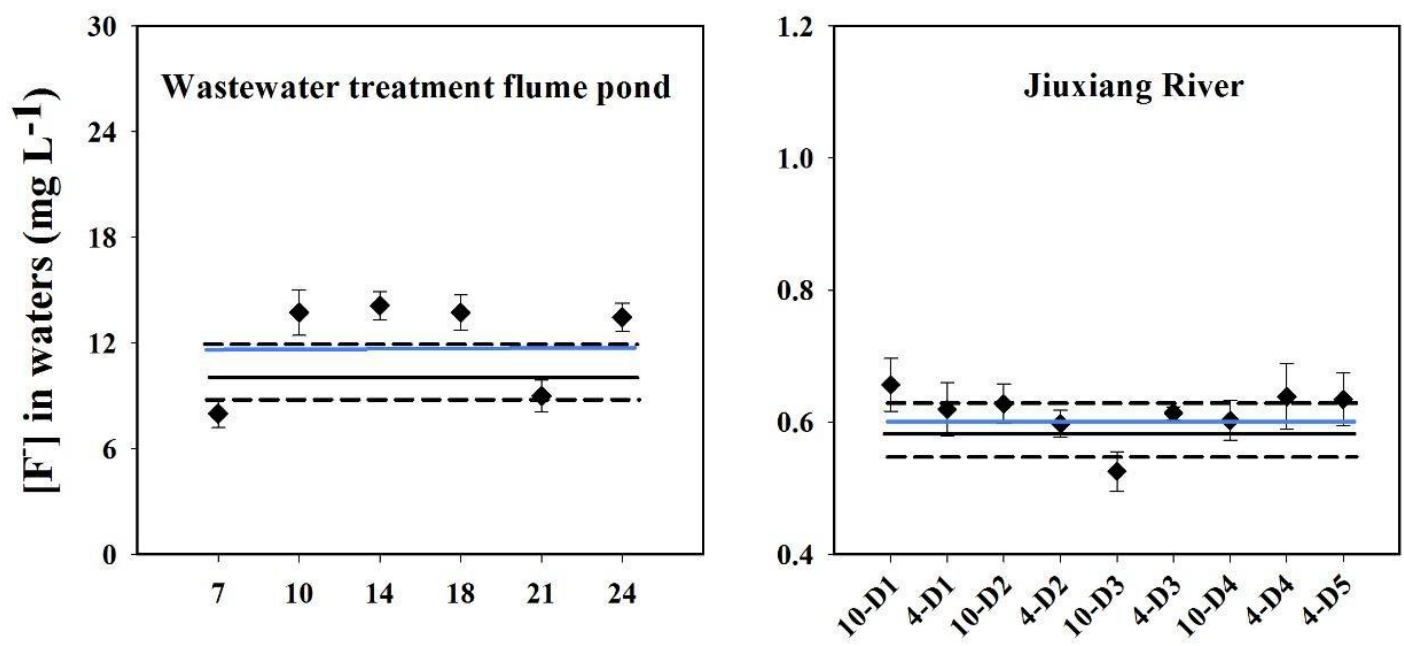

\section{Samping time (h)}

Fig. 3. Measurement of $\mathrm{F}^{-}$concentrations by two methods at different sampling times in surface water systems. The solid diamonds represent the concentrations of $\mathrm{F}^{-}$ measured by active sampling method in Wastewater treatment flume pond and Jiuxiang River, while the solid blue lines represent the averaged $\mathrm{F}^{-}$concentrations during whole sampling time. The solid black lines means the time-averaged concentrations of $\mathrm{F}^{-}$measured by DGT and the upper and lower dotted black lines mean the maximum and minimum DGT measured concentrations. For wastewater treatment flume pond, 7-24 stand for 7 am to $24 \mathrm{pm}$ in one day. For Jiuxiang River, 10-D1 and 4-D1 stand for 10 am and $4 \mathrm{pm}$ in day 1. 


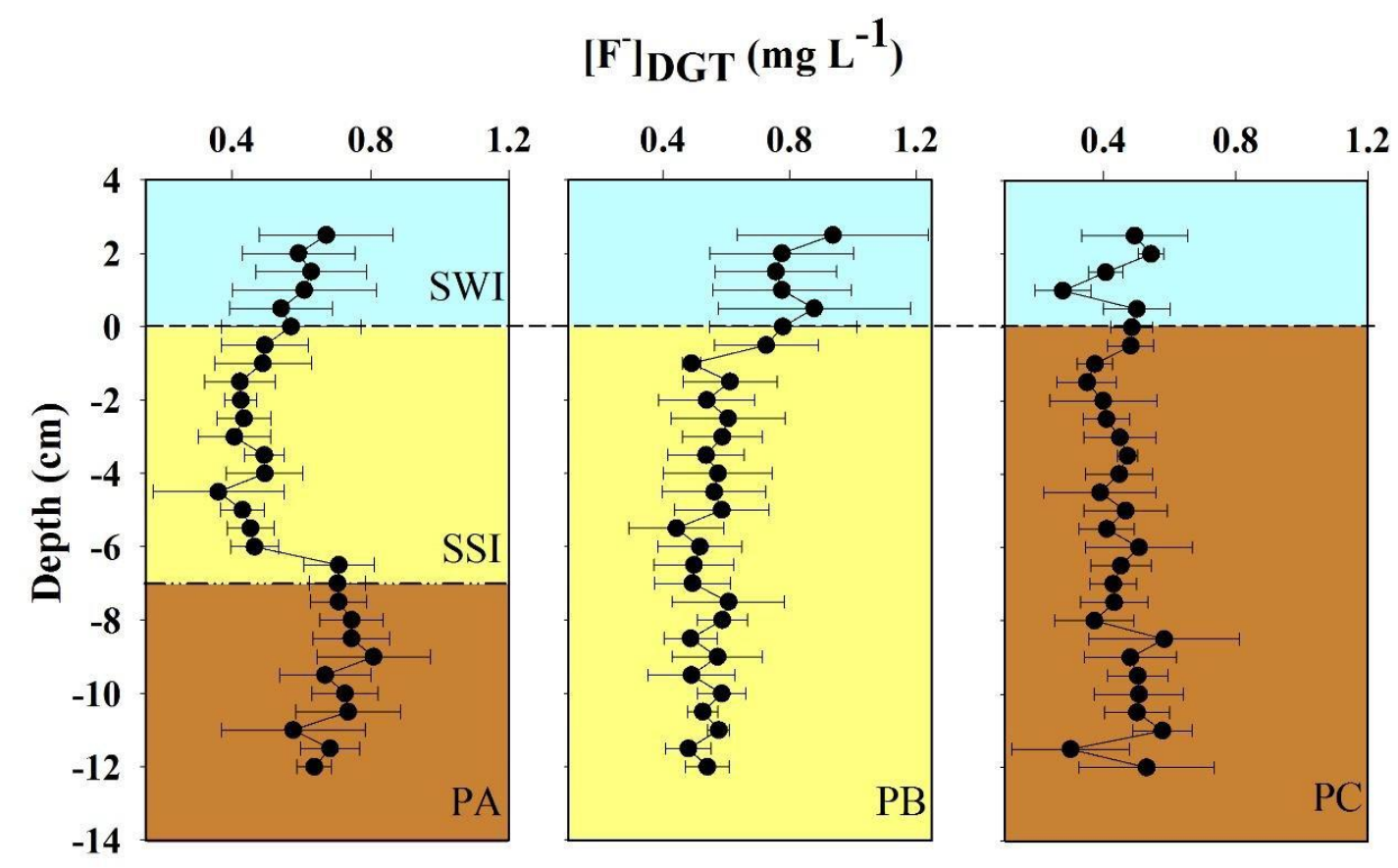

Fig. 4. 1D vertical concentration profiles of $\mathrm{F}^{-}$across the sediment-water interface (SWI) in PA, PB and PC, and the sand-silt interface (SSI) in PA of three sediments in Lake Luoma, light blue shows the overlying water, light yellow stands for the sand while brown represents the silt. Values are means \pm SD of three horizontal replicates. 

Electronic Supplementary Material (for online publication only)
Click here to download Electronic Supplementary Material (for online publication only): SI F-DGT 20160308.docx

\author{
(1)
}

